\title{
Analysis of Financial Feasibility of Nutmeg Syrup Business (Case Study in CV. Kie Raha, Ngade Village, Ternate City)
}

\author{
Mila Fatmawati ${ }^{1, *}$, Nurjanna Albaar ${ }^{2}$ \\ ${ }^{1}$ Department of Agribusiness, Faculty of Agriculture, Khairun University, Ternate, Indonesia \\ ${ }^{2}$ Department of Food Technology, Faculty of Agriculture, Khairun University, Ternate, Indonesia \\ *Corresponding author. Email: fatmawatimila82@gmail.com
}

\begin{abstract}
An effort on nutmeg agribusiness development can be implemented through agricultural product diversification, where the product is not only sale as primary product but it can be developed to the secondary product. The aim of this study is to analyze the financial feasibility of nutmeg syrup at KieRaha home industry in Ngade Kota Ternate as one of the biggest nutmeg syrup home industry can be used for a study case. The primary data collection is taken through observation, interview and documentation. There are some method analysis data such as Break Even Point (BEP), Net Present Value (NPV), Internal Rate of Return (IRR), Ratio B/C and Payback Period are used to identify the primary data received. The result shows that the break event point is occurring when the KieRaha home industry produced 129 bottles or with total revenue IDR 2.322.000 equal $\$ 167,25$ per each production. Meanwhile, NPV calculation with interest $12 \%$ resulted IDR 2.322.000 where the investigation at nutmeg syrup home industry will gain revenue IDR 10.590 .800 for 9 years according to the present value, which means this home industry is feasible to develop because the value is positive or more than 0 . Net B/C Ratio analysis resulted 1,427531083> 1, where the benefit received is outweight the cost so it possible to continue in the future. Payback Period analysis showsthat the payback period is 2 years and 10 months. Lastly, based on the financial feasibility analyze above, the nutmeg syrup home industry is adequate to continue.
\end{abstract}

Keywords: financial feasibility analysis, nutmeg syrup, BEP, NPV, Net B/C and Payback period

\section{INTRODUCTION}

Nutmeg (Myristica fragrans Houtt) is a native plant of Indonesia, which has been known as a spice plant since the 18 th century. Indonesia is the world's largest producer and exporter of seeds and mace $(70-75 \%)$. Other producing countries are in Grenada by $20-25 \%$, followed by India, Sri Lanka and Malaysia. The main markets for Indonesia's nutmeg exports (in terms of volume) are Vietnam, the United States, the Netherlands, Germany and Italy [1]. Post-harvest handling methods that are still traditional and are not hygienic with improvised equipment, cause Indonesian nutmeg commodity prices to be low. Efforts to increase the selling value of nutmeg can be done by processing nutmeg into essential oils, nutmeg oleoresin, and nutmeg [2]. North Maluku is famous as a city of spices producing nutmeg and cloves as well as being one of the largest nutmeg producers in the world. However, the raw materials that are available at this time are not fully utilized. Nutmeg is one of the primary commodities of the archipelago and has now been spread all over the world.
Even though there are many nutmegs producing countries, but nutmeg originating from the Banda Islands in Maluku remains the best in the world [3]

Efforts to develop nutmeg agribusiness need to be pursued through diversification of plantation products, by not only selling commodities in the form of primary products but also in the way of processed products. Likewise, with the nutmeg commodity in the city of Ternate, development needs to be pursued through diversification of its products. This diversification effort is part of postharvest handling activities that must be developed by needs. Postharvest handling activities aim to maintain the quality of fresh products, in order to stay primed up to consumers, reduce losses due to depreciation and damage, extend shelf life, increase economic value, with the hope that in addition to spurring economic growth, the region is also directed to increase employment opportunities, income, and welfare of farmers and society in general. 
Research results show that nutmeg is commonly used as a medicine for diarrhea, bloating, and improves digestibility and appetite [4]. Nutmeg is also efficacious as corigence, carminative, overcoming gastric spasms, rheumatic pain, insomnia, and mouth ulcers [5] even to eliminate nausea because it has antiemetic properties, which are chemical compounds that are useful for treating nausea [6]. The processing of nutmeg syrup did not eliminate bioactive compounds that could function as antioxidants, and nutmeg syrup contained the antioxidant capacity equivalent to $776 \mathrm{mgL} \mathrm{AEAC-}{ }^{1}$ percentage, total phenolic amounted to 141 mg.L GAE- ${ }^{-1}$ [7]. World over the nutmeg continues to be a prized spice because of its unique flavour and pharmaceutical properties. Grenada is the enviable position of supplying one-fourth of the world demand, which in turn provides a major source of foreign exchange earnings to the country as well as a major source of income for a large segment of the population. However, the industry continues to be negatively affected by a declining interest in the crop due to labour issues, lack of organization with respect to marketing, falling prices and increasingly stringent international quality regulations. The industry can benefit from innovations in primary processing which can shorten processing times and improve the quality of the dried nutmeg and mace. The industry can also benefit from the creativity and innovativeness of the processors which has given rise several local brands of nutmeg food and pharmaceutical products. Improvements in primary and secondary processing, coupled with stronger institutional support and the forging of key international linkages to address the marketing issues can be the key to not only the survival, but the success of the Grenadian nutmeg industry [8].

Ternate is one area in Indonesia that produces nutmeg. One of the processed products of nutmeg that has been done is nutmeg syrup, which is a drink from typical and unique nutmeg meat with a slightly sour taste. Not many of Ternate's specialty drinks are produced in packs. The development of the nutmeg syrup industry in Ternate is still deficient. Nutmeg syrup products in Ternate have only been used as souvenirs for guests or tourists visiting Ternate and have not been able to meet the demand from outside Ternate on a large scale because their production is still minimal. Home industry companies must make commitments for the future. A mistake in decision making can have serious consequences. If the company is too large in assets, then it can cause high depreciation and other expenses, which amount does not need to occur.

One of the home industries of the nutmeg syrup business is $\mathrm{CV}$. Kieraha in Ngade village, Ternate city. The purpose of this study was to analyze the financial feasibility of the Kieraha nutmeg syrup business in a home industry in the Ngade village in Ternate City. Financial feasibility analysis is carried out to see whether the business that will or has been run can provide benefits or not and is economically feasible. The financial aspect assessment includes how much it costs to realize the business, determining the amount of capital needed, and allocating its use efficiencies in the hope of optimizing profits. Also, the financial feasibility analysis is to find out the picture of future efforts and maintain the benefit that can be obtained. Therefore, the results of this study are expected to be a reference for companies to make decisions regarding their business activities and sustainability.

By using financial analysis, planned business feasibility is determined using five criteria, namely Break-Even Point (BEP) analysis, Net Present Value (NPV), Internal Rate of Return (IRR), Net Benefit-Cost Ratio (Net B / C) analysis and Payback Period (PP).

\section{METHODS}

\section{Research Location and Time}

This research was conducted at CV. Kie Raha, Ngade village, Ternate City. Determination of the location of research carried out deliberately (purposive). Site selection considerations are based because of the home business of nutmeg syrup CV. Kie Raha is one that is consistently producing and marketing reasonably smoothly. When the research was carried out for six months, from June to November 2018.

\section{Data source}

Sources of data in this study are primary and secondary data. Primary data in the form of direct data from the company in the way of observations and interviews with the leadership of CV. Kie Raha and processing employees. The required data from primary data regarding marketing mix, company layout, organizational structure, environmental management, business licensing, and financial data used for financial feasibility analysis. Secondary data were obtained from company management reports and related agencies in the form of documents, previous research, and others.

\section{Method of Collecting Data}

Data collection methods are carried out in several ways, as follows:

a. Observation

Observations were made by the writer to collect data directly to the CV. Kie Raha. Data obtained in the form of organizational structure, as well as various matters related to the service and cases, analyzed.

b. Interview

The author directly communicates with the data source. Communication is done by dialogue (question and answer) verbally.

c. Documentation

The author seeks and collects data obtained from existing documents or records stored in the company in 
the form of financial statements, records of income, cost of goods sold, and so forth.

\section{Data analysis method}

The data analysis method used in this research is to evaluate the financial feasibility of nutmeg syrup business using quantitative analysis tools, namely Break-Even Points (BEP), Net Present Value (NPV), Net Benefit-Cost Ratio (Net B / C), and Payback Period (PP) [9].Also, data to support the analysis in the form of fixed cost data and variable costs are used to determine the total production cost or total cost.

\section{Break-Even Point (BEP)}

BEP is a point of the amount of production or sales that must be done so that costs incurred can be covered again or the value where the profit received is zero [9]. The formula can be written as in:

$$
\mathrm{BEP} \text { unit }=\frac{\mathrm{FC}}{\mathrm{P}-\mathrm{VC}}
$$

Where:

$\mathrm{VC}=$ Variable cost

$\mathrm{FC}=$ Fixed Cost

$\mathrm{P}=$ Unit selling price

\section{Net Present Value (NPV)}

Net Present Value (NPV) is a method that calculates the difference between benefits or revenues and costs or expenses. NPV can be formulated as follows:

$$
\mathrm{NPV}=\sum_{\mathrm{t}=0}^{\mathrm{n}} \frac{B t-C t}{(1+i)^{t}}
$$

Information:

$\mathrm{Bt}=$ Benefit (farm receipt in the $t$-year)

$\mathrm{Ct}=$ Cost (farming costs in the t-year)

$\mathrm{n}=$ the economic life of the project (10 years)

$\mathrm{i}=$ applicable interest rate $(12 \%)$

This calculation is measured using the present value of money with the following criteria:

a. If the NPV is greater than zero, then the effort is declared feasible

b. If the NPV is smaller than zero, then the business is declared not feasible

c. If the NPV is equal to zero, then the business is declared in breakeven position.

\section{Benefit-Cost Ratio}

Benefit-Cost Ratio (Gross B / C) is a comparison between the revenue and benefits of an investment with the costs incurred. $\mathrm{B} / \mathrm{C}$ can be mathematically formulated as follows:

$$
\text { Net } B / C=\frac{\sum_{t=1}^{n} \frac{B t-C t}{(1+i)^{t}}}{\sum_{t=1}^{n} \frac{C t-B t}{(1+i)^{t}}}
$$

Information:

$\mathrm{Bt}=$ Benefit (gross receipts in the $\mathrm{t}$-year)

$\mathrm{Ct}=$ Cost (gross cost in the $\mathrm{t}$-year)

$\mathrm{n}=$ the economic life of the project

$\mathrm{i}=$ applicable interest rate

Criteria that can be obtained from Net B / C calculations include:

a. Net $\mathrm{B} / \mathrm{C}>1$, the business is profitable;

b. Net $\mathrm{B} / \mathrm{C}=1$, the business is unprofitable and not detrimental;

c. Net $\mathrm{B} / \mathrm{C}<1$, then the business is detrimental

\section{Payback Period}

Payback period (PP) is the investment appraisal of a project based on the payment of investment costs based on the net benefits of the project. Mathematically formulated as follows:

$\mathrm{PP}=\mathrm{n}+(\mathrm{a}-\mathrm{b}) /(\mathrm{c}-\mathrm{b}) \times 1$ year

Information :

$\mathrm{PP}=$ Payback Period

$\mathrm{n}=$ the last year where the amount of cash flow is still not biased to cover the initial investment

$\mathrm{a}=$ the amount of the initial investment

$\mathrm{b}=$ cumulative amount of cash flow in nth year

$\mathrm{c}=$ cumulative amount of cash flow in $\mathrm{n}+1$ year

Payback Period Assessment Criteria:

a. If the Payback Period is shorter than the economic life of the business, then the business is declared feasible

If the Payback Period is longer than the economic life of the business, then the project is declared ineligible.

\section{RESULTS AND DISCUSSION}

\section{Business Financial Feasibility Analysis}

This analysis or approach focuses on the micro approach, meaning that in the analysis or approach of the activities and results of a project seen from the interests of individuals or companies or the interests of the company's shareholders, namely the profits generated project (private return) or business profit [10].

In determining whether a business is feasible or not, the most important function is the financial aspect where the business can only be carried out if there is a funding budget. Financial aspects related to how to determine the needs of the number of funds and at the same time allocating them and finding sources of funds concerned efficiently, thus providing a promising level of profit for investors [11]. Business activities are said to be feasible if 
they offer financial benefits; on the contrary, business activities are said to be improper if the business does not provide financial benefits. The level of feasibility of a business can be assessed using investment criteria: a) Net Present Value (NPV), b) Internal Rate of Return (IRR), c) Benefit-Cost Ratio (BCR), d and Payback Period (PP) [12]. It also can be calculated the value of the BEP (breakeven point) so that it can be known and what is the minimum amount that must be produced. The "Kie Raha" nutmeg syrup business is a business that has been carried out for years because nutmeg has a productive life of tens of years. A business that is run in the long run usually needs to know it's worth by using a financial feasibility analysis tool or investment criteria tool. Investment criterion tools include, among others, BEP, NPV, IRR, B / C Ratio, and Payback Period Analysis.

\section{1) Break-Even Point (BEP)}

BEP is a point of the amount of production or sales that must be done so that costs incurred can be covered again or the value where the profit received is zero [9].

$$
\text { BEP unit }=\frac{\mathrm{FC}}{\mathrm{P}-\mathrm{VC}}
$$

Where :

$\mathrm{VC}=$ Variable cost

$\mathrm{FC}=$ Fixed Cost

$\mathrm{P}=$ unit selling price

Based on the data shown above, the BEP value can be calculated as follows:

$\mathrm{FC}=\mathrm{Rp} 550.000$

$\mathrm{VC}=\mathrm{Rp} 1.235 .000 / 90=\mathrm{Rp} 13.722$

$\mathrm{TC}=\mathrm{VC}+\mathrm{FC}$

$\mathrm{TR}=\mathrm{Q} \times \mathrm{P}$

$\mathrm{QE} \quad=\underline{\mathrm{FC}}$

$\mathrm{P}-\mathrm{VC}$

$$
\mathrm{QE} \quad=\frac{550.000}{(18.000-13.722)}
$$

$\mathrm{QE}=128,6$ or 129 bottles of nutmeg syrup

So TR $=129 \times \operatorname{Rp} 18.000$

$=\operatorname{Rp} 2.322 .000$

Based on the calculation above, it can be concluded that the break-even point will occur when the company produces 129 bottles or total revenue of $\mathrm{Rp} 2.322 .000$ at each time of production.

\section{Net Present Value (NPV)}

Net Present Value (NPV) is a method that calculates the difference between benefits or revenues and costs or expenses. NPV can be formulated as follows:

$$
\mathrm{NPV}=\sum_{\mathrm{t}=0}^{\mathrm{n}} \frac{B t-C t}{(1+i)^{t}}
$$

Information:

$\mathrm{Bt}=$ Benefit (business revenue in the t-year)

$\mathrm{Ct}=\mathrm{Cost}$ (operating costs in the $\mathrm{t}$-year)

$\mathrm{n}=$ the economic life of the project ( 10 years)

$\mathrm{i}=$ applicable interest rate $(6 \%)$

This calculation is measured using the present value of money with the following criteria:

If the NPV is more significant than zero, then the effort is declared feasible

If the NPV is smaller than zero,later the business is claimed not feasible

If the NPV is equal to zero, then the business is claimed in breakeven position.

Based on the calculation data, the NPV value of Rp 10.590 .800 is obtained, where the result is more significant than zero, so it can be concluded that the "Kie Raha" nutmeg syrup business is feasible.

\section{Benefit-Cost Ratio}

Benefit-Cost Ratio (Gross B / C) is a comparison between the revenue and benefits of an investment with the costs incurred. B / C can be mathematically formulated as follows:

$$
\text { Net } B / C=\frac{\sum_{t=1}^{n} \frac{B t-C t}{(1+i)^{t}}}{\sum_{t=1}^{n} \frac{C t-B t}{(1+i)^{t}}}
$$

Information:

$\mathrm{Bt}=$ Benefit (gross receipts in the $\mathrm{t}$-year)

$\mathrm{Ct}=$ Cost (gross cost in the $\mathrm{t}$-year)

$\mathrm{n}=$ the economic life of the project

$\mathrm{i}=$ applicable interest rate

Criteria that can be obtained from Net B / C calculations include:

Net B / C > 1, the business is profitable;

Net $\mathrm{B} / \mathrm{C}=1$, the business is unprofitable and not detrimental;

Net $\mathrm{B} / \mathrm{C}<1$, then the business is detrimental

Based on the research data obtained a Net B / C value of 1.427.531.083, which based on the criteria means Net B / C $>1$, the nutmeg syrup business "Kier Raha" can be concluded profitable or feasible.

\section{Payback Period}

Payback period (PP) is the investment appraisal of a project based on the payment of investment costs based on the net benefits of the project. Mathematically formulated as follows:

$\mathrm{PP}=\mathrm{n}+(\mathrm{a}-\mathrm{b}) /(\mathrm{c}-\mathrm{b}) \mathrm{x} 1$ year

Information:

PP $=$ Payback Period 
$\mathrm{n}=$ the last year where the amount of cash flow is still not biased to cover the initial investment

$\mathrm{a}=$ the amount of the initial investment

$\mathrm{b}=$ cumulative amount of cash flow in $\mathrm{nth}$ year

$\mathrm{c}=$ cumulative amount of cash flow in $\mathrm{n}+1$ year

Payback Period Assessment Criteria:

If the Payback Period is shorter than the economic life of the business, then the business is declared feasible

If the Payback Period is more extended than the economic growth of the business, then the project is declared unfeasible.

Based on the results of business calculations with an initial investment value of Rp. 24.472.000 the level of recurrence takes two years and ten months. So it can be said to be feasible.

\section{BEP analysis}

Based on the calculation above, it can be concluded that the break-even point will occur when the company produces 129 bottles or total revenue of IDR 2.322.000 equal $\$ 167,25$ at each time of production. In the field, up to now the nutmeg syrup business "Kie Raha" only produces as many as 90 bottles, but it still benefits because, in the calculation, it does not use the cost of illustrations as a basis for calculating fixed costs which is one of the elements in calculating Break- Event Points (BEP). Depreciation costs themselves are considered as costs, but in reality no cash is incurred.

\section{NPV analysis}

In the analysis of the financial feasibility of nutmeg farming, the NPV calculation results obtained with an interest rate of $12 \%$ produce an NPV value of $\mathrm{Rp}$. 2.068.963. Which shows that the investment in the nutmeg syrup business will provide a profit of RP 10,590,800 for nineyears, according to present value, which means the nutmeg syrup business is feasible to be developed because it produces a positive amount or more than 0 . As explained in theory according to Umar (2005: 200) which states that the NPV (Present Net Value) is the difference between the present value of an investment and the present value of net cash receipts (operational cash flow and terminal cash flow). To calculate the value now it is necessary to determine the applicable interest rate.

\section{Analysis of B / C Ratio}

Analysis of Net B / C Ratio produces a value of 1.427.531.083 $>1$, where the benefits obtained are more significant than the costs incurred, so the nutmeg syrup business is feasible to be continued.

As stated in the theory of $\mathrm{B} / \mathrm{C}$ Ratio is a comparison between the present value of benefits with the present value of costs, thus the benefit-cost ratio shows the benefits obtained each additional one rupiah expenditure $\mathrm{B}$ / C Ratio will describe the benefits and is worth doing if you have a B / C Ratio $\geq 1$, if the $\mathrm{B} / \mathrm{C}$ Ratio $=1$ then the business is not profitable and not losing, so it is up to the decision-maker to carry out or not. If $\mathrm{B} / \mathrm{C}$ Ratio $\leq 1$, the business is detrimental, so it is better not to be carried out [12].

\section{Payback Period}

Payback Period is known that the investment capital return period required in nutmeg farming is two years ten months. The paybackperiod (PBP) is a specificperiod, which shows the cumulative cash flow flows equal to the amount of investment in the form of present value. Payback period analysis in the feasibility study also needs to be displayed to find out how long the business/project being undertaken can only return the investment. The faster the return on investment costs for a project, the better the project is because the capital turnover is smoother, analysis calculates how much investment can be used back. Therefore, financially, nutmeg cultivation with IPM technology is feasible and profitable to be cultivated [13].

\section{CONCLUSION}

Based on the results of the business feasibility analysis of the financial aspects of four aspects, namely BEP, NPV, Net B / C and Payback Period, the calculation shows that the nutmeg syrup business "Kie Raha" Ngade village, Ternate City is feasible. This business development has quite a good economic potential and is possible to be developed, shown from the calculation of the financial feasibility analysis.

Based on the results of the interview, and the results of the research, the suggestions that can be given are as follows:

1. The government should pay attention in the form of capital assistance or training for home entrepreneurs in the city of Ternate, to increase the income and welfare of the community as the utilization of natural resources in the form of abundant nutmeg and not yet utilized optimally.

2. Academics can provide training or guided activities in the field of product diversification, bookkeeping, and other activities that can improve product quality and determine prices and separate company assets from personal assets.

3. The government and academics can help the product marketing process by giving souvenirs to every guest who comes to Ternate.

\section{ACKNOWLEDGMENT}

Author would like to thank to owner of nutmeg syrup business CV. Kie Raha who have provided informations and discussions in completing this study. 


\section{REFERENCES}

[1] Krishnamonorthy, B and J. Rema. 2001. Handbook of Herb and spices, Volume 1: Nutmeg and Mace. CRC Press. Baco Raton Bostan New York Washington DC.

[2] Rodianawati, I., P. Hastuti and M.N. Cahyanto. 2015. Nutmeg's (Myristica fragrans Houtt) Oleoresin: Effect of Heating to Chemical Compositions and Antifungal Properties. Procedia Food Science.3:244-254.

[3] Balitka. 2010. Revitalisasi Perkebunan Pala Siau, Sulawesi Utara. Warta Penelitian dan Pengembangan Pertanian.32(1): 4-6.

[4] Astawan M. 2008. Pala, Mujarab buat Perut. Download: http://health.kompas.com/read/2008/09/26/162 33198/Pala.Mujarab.buat.Perut. Diakses: 25 Maret 2013.

[5] Alegantina S dan D Mutiatikum. 2009. Pengembangan dan Potensi Pala (Myristica fragrans). Jurnal Kefarmasian Indonesia. 1(2): 64-70.

[6] Cahyo. 2012. Khasiat Buah Pala Bagi Kesehatan. Download: http://bagi.me/2012/12/khasiatbuahpala-bagi-kesehatan/. Diakses: 25 Maret 2013.
[7] Faridah DN, S Yasni, A Suswantinah dan GW Aryani. 2013. Pencirian Mutu Kimiawi dan Mikrobiologis Produk Bandrek Instan dan Sirup Buah Pala (Myristica fragrans). Jurnal Ilmu Pertanian Indonesia. 18(1): 43-48.

[8] Ranjit, H.Sing. Clement K. Sankat. Saheeda Mujaffar. 2003. The Nutmeg and Spice Industry in Grenada: Innovation and Competitiveness. Present at Workshop on The Role Of science, Technology and innovation in Increasing Competitiveness in The Productive Sector.

[9] Kadariah. 2001. Evaluasi Proyek : Analisis Ekonomis. Lembaga Penerbitan Fakultas Ekonomi Universitas Indonesia. Jakarta.

[10] Lihan dan Yogi. 2009. Studi Kelayakan Bisnis. Poliyamawidya Pustaka. Jakarta

[11] Husen, abrara. 2009. Manajemen Proyek. Andi Offset. Yogyakarta.

[12] Ibrahim, H.M.Y. 2009. Studi Kelayakan Bisnis. Rineka Cipta. Jakarta.

[13] Muttaqin HM., Sofyan., Hakim, Lukman. 2019. Financial Feasibility of Nutmeg Cultivation with the Aplication of Integrated Pest Management Technology. International Journal of Multicultural and Multireligious Under standing.Vol 6 Issue 1. February 2019. Page 519-528. 